\title{
Non-Nucleotide RNA-Dependent RNA Polymerase Inhibitor That Blocks SARS-CoV-2 Replication
}

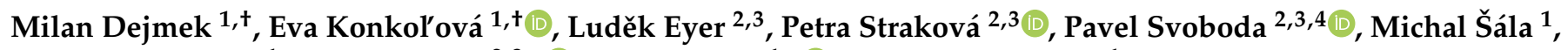 \\ Kateřina Krejčová ${ }^{1}$, Daniel Růžek ${ }^{2,3, * \mathbb{D}}$, Evzen Boura ${ }^{1, * \mathbb{C}}$ and Radim Nencka ${ }^{1, *}$ \\ 1 Institute of Organic Chemistry and Biochemistry, Czech Academy of Sciences, Flemingovo náměstí 542/2, \\ 16000 Praha, Czech Republic; dejmek@uochb.cas.cz (M.D.); eva.konkolova@uochb.cas.cz (E.K.); \\ sala@uochb.cas.cz (M.̌̌.); katerina.krejcova@uochb.cas.cz (K.K.) \\ 2 Veterinary Research Institute, Emerging Viral Diseases, Hudcova 296/70, 62100 Brno, Czech Republic; \\ eyer@vri.cz (L.E.); strakova.p@centrum.cz (P.S.); svoboda@vri.cz (P.S.) \\ 3 Institute of Parasitology, Biology Centre of the Czech Academy of Sciences, Branišovská 1160/31, \\ 37005 České Budějovice, Czech Republic \\ 4 Department of Pharmacology and Pharmacy, Faculty of Veterinary Medicine, \\ University of Veterinary Sciences Brno, Palackého tř. 1946/1, 61242 Brno, Czech Republic \\ * Correspondence: ruzekd@paru.cas.cz (D.R.); boura@uochb.cas.cz (E.B.); nencka@uochb.cas.cz (R.N.) \\ + These authors contributed equally.
}

Citation: Dejmek, M.; Konkol'ová, E.; Eyer, L.; Straková, P.; Svoboda, P.; Šála, M.; Krejčová, K.; Růžek, D.; Boura, E.; Nencka, R. Non-Nucleotide RNA-Dependent RNA Polymerase Inhibitor That Blocks SARS-CoV-2 Replication. Viruses 2021, 13, 1585. https://doi.org/10.3390/v13081585

Academic Editor: Tomas Ruml

Received: 4 July 2021

Accepted: 9 August 2021

Published: 11 August 2021

Publisher's Note: MDPI stays neutral with regard to jurisdictional claims in published maps and institutional affiliations.

Copyright: (C) 2021 by the authors. Licensee MDPI, Basel, Switzerland. This article is an open access article distributed under the terms and conditions of the Creative Commons Attribution (CC BY) license (https:// creativecommons.org/licenses/by/ $4.0 /)$.

\begin{abstract}
SARS-CoV-2 has caused an extensive pandemic of COVID-19 all around the world. Key viral enzymes are suitable molecular targets for the development of new antivirals against SARSCoV-2 which could represent potential treatments of the corresponding disease. With respect to its essential role in the replication of viral RNA, RNA-dependent RNA polymerase (RdRp) is one of the prime targets. HeE1-2Tyr and related derivatives were originally discovered as inhibitors of the RdRp of flaviviruses. Here, we present that these pyridobenzothiazole derivatives also significantly inhibit SARS-CoV-2 RdRp, as demonstrated using both polymerase- and cell-based antiviral assays.
\end{abstract}

Keywords: non-nucleotide inhibitor; RNA-dependent RNA polymerase; SAR-CoV-2; COVID-19; antiviral agents

\section{Introduction}

Coronaviruses are positive-sense RNA viruses that cause numerous important human and animal diseases. These viruses are classified into four genera including Alphacoronavirus and Deltacoronavirus [1]. While infectivity of gammacoronaviruses and deltacoronaviruses is limited to animals, mostly birds [2], alphacoronaviruses and betacoronaviruses comprise numerous mammalian and human pathogens [3,4]. Important alphacoronaviruses are Human coronaviruses (HCoVs) 229E and NL63, as well as Feline coronavirus (FIPV) and Porcine epidemic diarrhea virus (PEDV). Betacoronaviruses include the rest of human coronaviruses (HCoV-OC43, HCoV-HKU1, Severe acute respiratory syndrome coronavirus (SARS-CoV and SARS-CoV-2), Middle East respiratory syndrome coronavirus (MERS$\mathrm{CoV})$ ) and a number of other animal pathogens. While coronaviruses that have persisted in the human population for a long time (HCoV-229E, HCoV-NL63, HCoV-OC43, and HCoVHKU1) cause milder upper respiratory illnesses, SARS-CoV, SARS-CoV-2, and MERS-CoV are highly pathogenic viruses causing severe lower respiratory illness that can progress to life-threatening pneumonia with significant mortality rates [5,6].

SARS-CoV-2 is responsible for the largest pandemic of acute viral disease that our world has faced since the Spanish flu [7]. Although the mortality of this disease is not as high as in that of SARS-CoV or MERS-CoV infections, the disease caused by this virus (COVID-19) has significantly changed the world in which we live [8]. In particular, mortality in older age groups is alarming [9], and although we already have vaccines [10] as well as several drugs based on both monoclonal antibodies and small molecules, the 
effectiveness of these treatments is limited by several factors, including the high mutation rate of this virus [11]. Therefore, it is essential that pharmaceutical research focuses on the widest possible range of molecular targets and that we seek to find substances that we can use in combination with already known drugs to reduce the risk of the development of resistance. One of the main molecular targets in viruses is their polymerase, which is responsible for the replication of their genetic information. The example of HIV has shown that a combination of nucleoside and non-nucleoside reverse transcriptase inhibitors can lead to a very effective therapy for this serious disease [12]. Therapies for diseases caused by other viral pathogens, such as hepatitis B and C viruses (HBV and $\mathrm{HCV}$ ), also rely largely on polymerase inhibitors $[13,14]$. Therefore, it is not surprising that the main approach for the development of new antivirals against SARS-CoV-2, as well as other coronaviruses, is based on targeting the RNA-dependent RNA polymerase (RdRp) as a central replication enzyme of the virus [15]. RdRp is part of the large coronaviral replication complex that also includes RNA methyltransferases, helicase, nsp9, and probably the N protein [16]. The coronaviral $\mathrm{RdRp}$ is a highly conserved heterotrimeric protein complex that is composed of two accessory but essential proteins (nsp7 and nsp8) and the catalytic subunit nsp12 [17]. While the first nucleoside-based RdRp inhibitor has already been approved by the relevant authorities around the world [18], information on potent non-nucleoside inhibitors of this key enzyme is rather scarce. Recently, suramin was reported as a potent non-nucleoside inhibitor of SARS-CoV-2 RdRp, and its mode of action was supported by a cryo-EM structure [19]. Also, several natural products including corilagin [20] and lycorine [21] exert inhibition potency against SARS-CoV-2 RdRp. Although efforts have been made to identify new non-nucleoside inhibitors of this enzyme by in silico methods since the beginning of the pandemic, the results of these studies are unfortunately rarely supported by experimental data [22].

HeE1-2Tyr (compound 16) was initially identified by Tarantino et al. as a potent inhibitor of RdRp from Dengue virus (DENV), West Nile virus, and Yellow fever virus, all members of genus Flavivirus [23-26]. This compound was crystalized in complex with the RdRp from DENV 3. It was shown that the drug binds on the thumb side of the RNAbinding site, with significant movement of the priming loop. The authors also suggested that there is another possible binding site of the compound that is hidden by the priming loop. This hypothesis has been supported by point mutation experiments [23].

Here, we report on the identification of HeE1-2Tyr (16) and its derivatives as potential inhibitors of SARS-CoV-2 RdRp. The drugs exert activity not only against SARS-CoV-2 but also against FIPV. Our study started with the screening of our small collection of various nucleoside triphosphate and non-nucleoside inhibitors of polymerases from different viruses against SARS-CoV-2 RdRp and, in parallel, a screening of our complementary nucleoside, nucleotide prodrug, and non-nucleoside derivative library against SARS-CoV-2 in cell-based assays. To our surprise, we identified HeE1-2Tyr (16), which we prepared as a standard for our studies on flavivirus RdRps, as an effective inhibitor of SARS-CoV-2 RdRp that also exerted significant activity against the virus in cell cultures.

\section{Material and Methods}

\subsection{Protein Expression and Purification}

SARS-CoV-2 nsp7 (GeneBank: YP_009725303), nsp8 (GeneBank: YP_009725304,) and nsp12 (GeneBank: YP_009725307) genes were commercially synthesized as codonoptimized for E. coli (Invitrogen). The gene for nsp7 was cloned into a modified pRSF-Duet vector containing an N-terminal $6 \times$ His tag, followed by a GB1 solubility tag, a $10 \times$ Asp spacer sequence, and a tobacco etch virus (TEV) protease cleavage site in cloning site 1. The nsp8 gene was subsequently cloned into cloning site 2 without any tag. The gene for nsp12 was cloned into the pAceBac vector with cleavable $6 \times$ His on the C-terminus. The nsp7/nsp8 protein complex was expressed and purified as described previously for truncated nsp7/nsp8 in E. coli [27]. The SARS-CoV-2 nsp12 plasmid was used to prepare recombinant baculovirus Sf9 insect cells that were infected at $1-2 \times 10^{6} \mathrm{cell} / \mathrm{mL}$ with the 
tertiary recombinant baculovirus. After $68 \mathrm{~h}$, the cells were collected by centrifugation, resuspended in lysis buffer ( $50 \mathrm{mM}$ HEPES 7.4, $300 \mathrm{mM} \mathrm{NaCl}, 20 \mathrm{mM}$ imidazole, $3 \mathrm{mM}$ $\mathrm{MgCl}_{2}, 10 \%(v / v)$ glycerol, and $3 \mathrm{mM} \beta$-mercaptoethanol) and sonicated (Q700 Sonicator, QSonica). The lysate was subsequently cleared by centrifugation, and the supernatant was incubated with Ni-NTA agarose (Thermo Scientific) and washed with lysis buffer; finally, the protein was eluted with lysis buffer supplemented with $300 \mathrm{mM}$ imidazole. Nsp12 protein was further purified by size-exclusion chromatography using Superdex 200 16/600 (GE Healthcare) in size-exclusion buffer (20 mM HEPES 7.4, $300 \mathrm{mM} \mathrm{NaCl}, 1 \mathrm{mM} \mathrm{MgCl}$, $10 \%(v / v)$ glycerol, and $3 \mathrm{mM} \beta$-mercaptoethanol). Fractions containing the pure nsp12 protein were concentrated to $5 \mathrm{mg} / \mathrm{mL}$, flash-frozen, and stored at $-80^{\circ} \mathrm{C}$ until needed.

\subsection{Fluorescence-Based Primer Extension Polymerase Assay}

The polymerase activity was determined in a primer extension reaction using a fluorescently labeled primer (HEX-5'-AGAACCUGUUGAACAAAAGC- $3^{\prime}$ ) and an RNA template ( $5^{\prime}$ - AUUAUUAGCUGCUUUUGUUCAACAGGUUCU-3'). The polymerase activity assay was performed in a total volume of $10 \mu \mathrm{L}$ containing the reaction buffer $(10 \mathrm{mM}$ Tris $\mathrm{pH}$ 8.0, $2 \mathrm{mM} \mathrm{MgCl} 2,10 \mathrm{mM} \mathrm{KCl}, 1 \mathrm{mM} \beta$-mercaptoethanol), $10 \mu \mathrm{M} \mathrm{NTPs}, 0.5 \mu \mathrm{M} \mathrm{T} / \mathrm{P}$ complex, $1 \mu \mathrm{M}$ nsp12 polymerase, and $3 \mu \mathrm{M} \mathrm{nsp} 7 / \mathrm{nsp} 8$ complex. The reactions were incubated for $1 \mathrm{~h}$ with various concentrations of the inhibitors tested at $30^{\circ} \mathrm{C}$ and stopped by adding $20 \mu \mathrm{L}$ of the stop buffer ( $80 \%$ formamide, $50 \mathrm{mM}$ EDTA). The samples were denatured at $95{ }^{\circ} \mathrm{C}$ for $10 \mathrm{~min}$, and primer extension products were separated on a $20 \%$ denaturing polyacrylamide gel (8 M urea, $1 \times$ TBE, $20 \%$ acrylamide (19:1)) and scanned on a Typhoon 5 Biomolecular Imager (GE Healthcare).

\subsection{Radioactivity-Based Primer Extension Polymerase Assay}

The assay was performed as above, except that the reaction mixture contained $0.5 \mu \mathrm{M}$ T/P complex (P-5'-AGAACCUGUUGAACAAAAGC-3' ' T-5'-U25-GCUUUUGUUCAACA GGUUCU- $3^{\prime}$ ) and $0.01 \mu \mathrm{Ci} / \mu \mathrm{L}$ [ $\left.\alpha-32 \mathrm{P}\right]-\mathrm{ATP}$. After incubation, $5 \mu \mathrm{L}$ of the reaction mixtures was spotted on an anion-exchange cellulose filter paper (WhatmanTM Grade DE81 DEAE cellulose paper; GE Healthcare) in triplicates. The Whatman filter was then dried, subsequently washed with $0.125 \mathrm{mM} \mathrm{Na}_{2} \mathrm{HPO}_{4}$, water, and ethanol, and dried again. The dry filter paper was then analyzed using phosphorimaging, the plate was scanned on Amersham Typhoon 5 Biomolecular Imager (GE Healthcare), products were quantified with Image Studio Lite (LI-COR), and the data were processed using GraphPad version 6 (GraphPad Prism version 6, GraphPad Software, San Diego, CA, USA).

\subsection{Viruses and Cell Lines}

Two representatives of the Coronaviridae family, i.e., SARS-CoV-2 (strain SARS-CoV2/human/Czech Republic/951/2020 isolated from a clinical sample at the National Institute of Health, Prague, Czech Republic, and kindly provided by Dr. Jan Weber, Institute of Organic Chemistry and Biochemistry, Prague, Czech Republic) and feline infectious peritonitis virus (FIPV, ATCC VR990, a pathogen of domestic cats and other felines), were used for our antiviral cell-based studies. The experiments with the live coronaviruses were performed in our BSL3 facility.

Vero cells (ATCC CCL-81, African Green Monkey, adult kidney, epithelial) and Vero E6 cells (ATCC CRL-1586) were cultured in Dulbecco's modified Eagle's medium (DMEM) supplemented with $10 \%$ newborn calf serum, $100 \mathrm{U} / \mathrm{mL}$ penicillin, $100 \mu \mathrm{g} / \mathrm{mL}$ streptomycin, and $1 \%$ glutamine (Sigma-Aldrich, Prague, Czech Republic) at $37^{\circ} \mathrm{C}$ and $5 \% \mathrm{CO}_{2}$. Colorectal adenocarcinoma cells (CaCo-2, ATCC HTB-37) were grown in DMEM medium, containing, 20\% newborn calf serum with $100 \mathrm{U} / \mathrm{mL}$ penicillin, $100 \mathrm{\mu g} / \mathrm{mL}$ streptomycin, and $1 \%$ L-glutamine (Sigma-Aldrich, Prague, Czech Republic) at $37^{\circ} \mathrm{C}$ and $5 \% \mathrm{CO}_{2}$. Felis catus kidney cortex cells (CRFK, ATCC CCL-94) were grown in DMEM supplemented with $10 \%$ newborn calf serum, $100 \mathrm{U} / \mathrm{mL}$ penicillin, $100 \mu \mathrm{g} / \mathrm{mL}$ streptomycin, and $1 \%$ glutamine (Sigma-Aldrich, Prague, Czech Republic) at $37^{\circ} \mathrm{C}$ and $5 \% \mathrm{CO}_{2}$. Vero (ATCC 
CCL-81), CaCo-2 (ATCC HTB-37), and CRFK (ATCC CCL-94) cells were used for antiviral and cytotoxicity assays, and Vero E6 cells (ATCC CRL-1586) were used to perform plaque assays.

\subsection{Cytotoxicity Studies}

Vero (ATCC CCL-81), CaCo-2 (ATCC HTB-37), and CRFK (ATCC CCL-94) cells were seeded into each well of 96-well microtitrate plates (approx. $2 \times 10^{4}$ cells per a well) and were incubated for $24 \mathrm{~h}$ at $37{ }^{\circ} \mathrm{C}$ and $5 \% \mathrm{CO}_{2}$. Cell monolayers in 96-well plates were treated with the compounds remdesivir, $\operatorname{HeE} 1-2 \operatorname{Tyr}(\mathbf{1 6}), \mathbf{1 7}$, or 18 at the concentration of $50 \mu \mathrm{M}$ or with $1 \%$ DMSO $(w / w)$ (for the initial screening; Vero and CRFK cell lines) or with the compounds remdesivir, HeE1-2Tyr (16) and $\mathbf{1 7}$ in concentration ranges from 0 to $50 \mu \mathrm{M}$ (for dose-response studies; 2-fold dilutions, three wells per concentration; Vero, CaCo-2, and CRFK cell lines) and cultured for $48 \mathrm{~h}$. The cytotoxic activity of the compounds was determined in terms of cell viability using a Cell Counting Kit-8 (Dojindo Molecular Technologies, Munich, Germany) following the manufacturer's instructions. The assay is based on the quantitative reduction of WST-8 tetrazolium salt to yellow formazan by cellular dehydrogenases. Cell viability was estimated as the percentage of colorimetric absorbance at $450 \mathrm{~nm}$ of the compound-treated cells relative to the absorbance of mock-treated cells. The concentration of compound that reduced cell viability by $50 \%$ was considered the $50 \%$ cytotoxic concentration $\left(\mathrm{CC}_{50}\right)$.

\subsection{Antiviral Efficacy of the Studied Compounds in Cell-Based Assays}

To study the antiviral effects of compounds HeE1-2Tyr (16), 17, and 18, we used a viral titer reduction assay. Vero (ATCC CCL-81), CaCo-2 (ATCC HTB-37), and CRFK (ATCC CCL-94) cells were seeded into each well of 96-well microtitrate plates (approx. $2 \times 10^{4}$ cells per a well) and incubated for $24 \mathrm{~h}$ at $37^{\circ} \mathrm{C}$ and $5 \% \mathrm{CO}_{2}$. Then, the medium was aspirated, replaced with $200 \mu \mathrm{L}$ of fresh medium containing compounds HeE1-2Tyr (16), 17, or 18 at the concentration of $50 \mu \mathrm{M}$ (for the initial screening) or with compounds HeE1-2Tyr (16) or 17 in the concentration range of 0 to $50 \mu \mathrm{M}$ (for dose-response antiviral studies; 2-fold dilution, three wells per compound). The treated cells were simultaneously inoculated with SARS-CoV-2 (for Vero and CaCo-2 cells) or FIPV (for CRFK cells) at an MOI of 0.1 and incubated for an additional $48 \mathrm{~h}$. Virus-infected cells treated with remdesivir (at the same concentrations) or DMSO $(1 \% w / w)$ were used as positive and negative controls, respectively. Viral titers were determined from the collected supernatant media by a plaque assay and used to construct dose-response curves (dependence of the viral titers [PFU/mL] on the compound concentration $[\mu \mathrm{M}]$ ) and inhibition curves (dependence of the inhibition percentage on the compound concentration $[\mu \mathrm{M}]$ ) and for calculation of the $50 \%$ effective concentrations $\left(\mathrm{EC}_{50}\right.$; the concentration of compound required to inhibit the viral titer by $50 \%$ compared to the control value).

\subsection{Plaque Assay}

Plaque assays were performed using Vero E6 cells (ATCC CRL-1586) as described previously $[28,29]$. Briefly, 10 -fold dilutions of SARS-CoV-2 or FIPV were prepared in 24-well tissue culture plates, and the cells were added to each well $\left(0.6-1.5 \times 10^{5}\right.$ cells per well). After a $4 \mathrm{~h}$ incubation at $37^{\circ} \mathrm{C}$ and $5 \% \mathrm{CO}_{2}$, the suspension was overlaid with $1.5 \%$ $(w / v)$ carboxymethylcellulose in a two-fold concentrated DMEM medium. Following a 5-day incubation at $37{ }^{\circ} \mathrm{C}$ and $5 \% \mathrm{CO}_{2}$, the infected plates were washed with phosphatebuffered saline, and the cell monolayers were stained with naphthalene black. The virus titer was expressed as plaque-forming units (PFU)/mL.

\section{Results and Discussion}

Although the synthesis of HeE1-2Tyr (16) and its derivatives has been well documented by work of Tarantino et al., we devised a modified approach in order to have easier access to a broader range of substituents in the 8-OH position of the benzothiazolo 
pyridinone (Scheme 1). To achieve this goal, we decided to protect the 5-OH group of the benzothiazole throughout the stages of central core construction. This way, the alkyl substituent could be introduced by the Mitsunobu reaction just prior to the introduction of the amino acid residue. After initial experiments with a TBDMS, which proved difficult to install and not very stable, we decided to use benzyl for this purpose. The 2-methyl group was then converted to an ethyl acetate by a reaction of an appropriate salt with ethyl carbonate. By using LiHMDS we achieved a very good yield in a short reaction time compared to methods using sodium hydride. A dimethylaminomethylene group was then introduced by the Vilsmeier-Haack reaction, and the pyridinone ring was subsequently closed by heating compound 4 with a neat acyl anhydride-acetic or phenylacetic. The benzyl group was comfortably cleaved using methansulfonic acid, providing compounds suitable for the Mitsunobu reaction, which afforded products 9 and 11, respectively. Workup of compounds 5-8 proved to be very easy, as these compounds are very poorly soluble, and reaction conversions are high. The rest of the synthesis was performed in a similar way as reported by Tarantino et al. An ethyl ester function was saponified, and $L$-Tyrosine and $L$-Phenylalanine methylesters, respectively, were connected to the free carboxylic acid by EDC-HOBt peptide coupling. This set of conditions proved to provide the best yields in the short optimization we performed. This procedure gave HeE1-2Tyr (16), as well two novel analogues 17 and 18, in excellent yields. Detailed descriptions of the synthesis is provided in the Supplementary File.<smiles>CCOC(=O)/C(=C/N(C)C)c1nc2cc(OC(C)(C)C)ccc2s1</smiles>

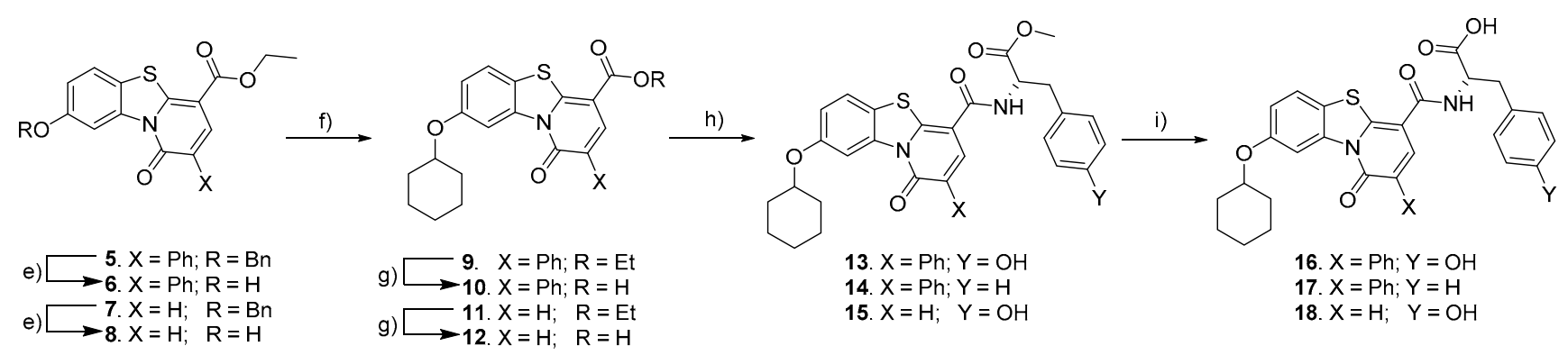

a) $\mathrm{BnOH}, \mathrm{PPh}_{3}$ DIAD, dioxane, RT, $48 \mathrm{~h}, 96 \%$; b) LiHMDS, (EtO) ${ }_{2} \mathrm{CO}, \mathrm{THF},-78^{\circ} \mathrm{C}$ to RT, $30 \mathrm{~min}, 82 \%$; $\mathrm{POCl}_{3} \mathrm{DMF}, 90^{\circ} \mathrm{C}, 30 \mathrm{~min}, 81 \%$; ) Respective anhydride, $100^{\circ} \mathrm{C}, 5 \mathrm{~h}, 99 \%$ for $5,94 \%$ for 7 ; e) $\mathrm{CH}_{3} \mathrm{SO}_{3} \mathrm{H}, \mathrm{DCM}, \mathrm{RT}, 3 \mathrm{~h}, 76 \%$ for $\mathbf{6}, 82 \%$ for 8 ; f) Cyclohexanol, PPh $\mathrm{CIAD}_{3}$, dioxane $\mathrm{RT}, 48 \mathrm{~h}, 89 \%$ for $9,87 \%$ for $11 ; \mathrm{g}) \mathrm{NaOH}, \mathrm{MeOH}-\mathrm{H}_{2} \mathrm{O}$, reflux, $3 \mathrm{~h}, 84 \%$ for $10,94 \%$ for 12 ; h) TyrOMe. HCl or PheOMe. HCl, EDC, HOBt, TEA, DCM, DMF, RT, $12 \mathrm{~h}, 92 \%$ for $13,91 \%$ for $14,92 \%$ for 15 ; i) LiOH, THF- $\mathrm{H}_{2} \mathrm{O}, 30 \mathrm{~min}, 88 \%$ for $16 ; 90 \%$ for $17,88 \%$ for 18.

Scheme 1. Synthetic pathway to HeE1-2Tyr (16) and its derivatives.

Our in vitro RdRp assay confirmed the inhibitory effect of compounds HeE1-2Tyr (16), 17, and 18 against SARS-CoV-2 polymerase. The compounds were initially tested at one concentration $(100 \mu \mathrm{M})$, which confirmed that compounds HeE1-2Tyr (16), 17, and 18 inhibit SARS-CoV-2 RdRp. Subsequently, the RdRp assay was used to determine the $\mathrm{IC}_{50}$ values. Surprisingly, compound HeE1-2Tyr (16) was found to be the best inhibitor, with $\mathrm{IC}_{50}$ of $27.6 \pm 2.1 \mu \mathrm{M}$, while the inhibition effect of compound 18 was rather weak $\left(\mathrm{IC}_{50}=85.5 \pm 2.0 \mu \mathrm{M}\right.$, Figure 1$)$. 

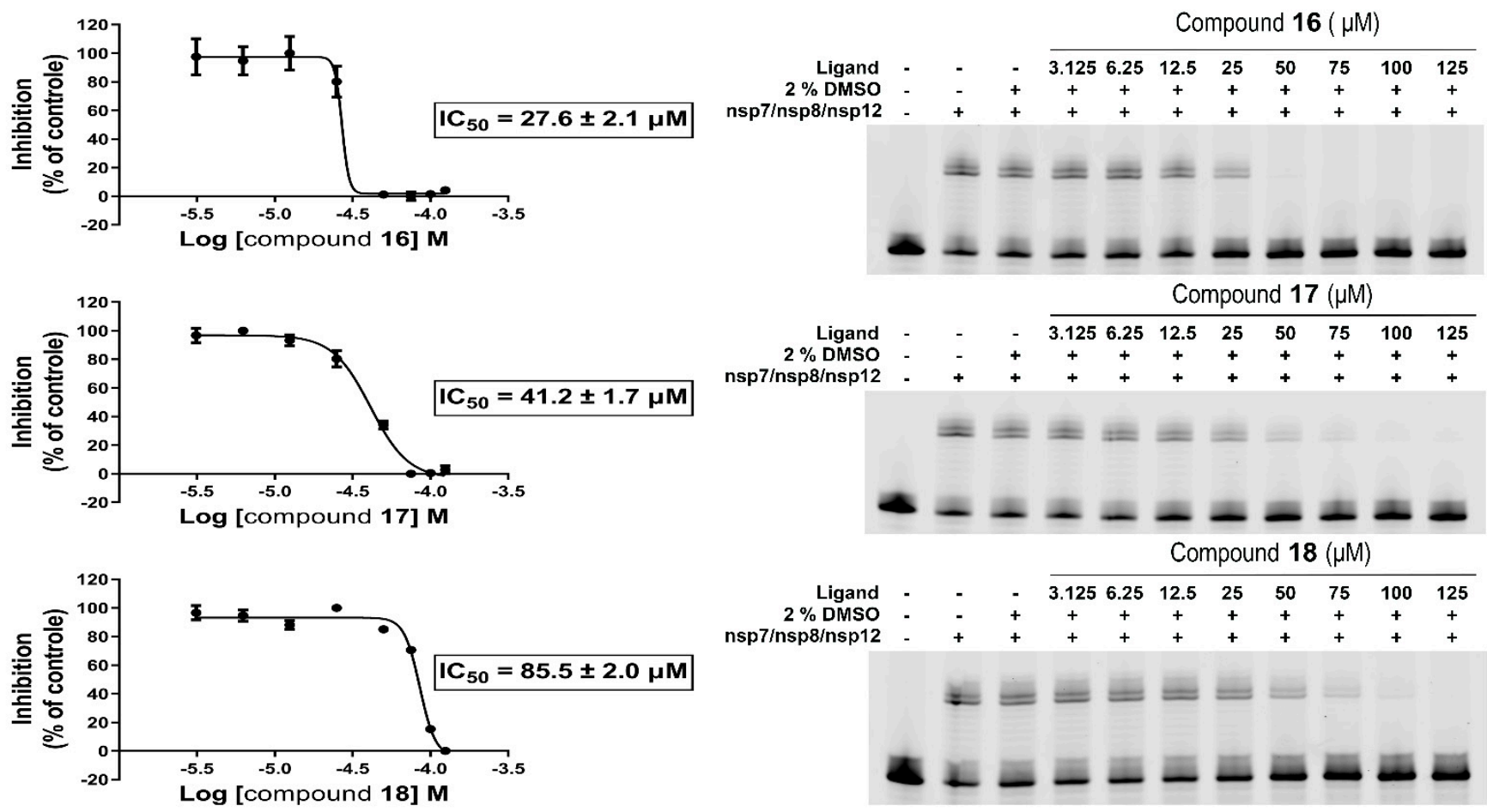

Figure 1. Inhibitions of SARS-CoV-2 RdRp by compounds 16, 17, and 18. (left) $\mathrm{IC}_{50}$ values were established for each tested compound using a radioactive primer extension assay. Error bars represent the standard error of the mean $(n=3)$. (right) A fluorescence-based primer extension assay. Formation of the 40-nt product decreases with increasing concentration of the compound.

Based on our findings that the compounds showed inhibitory activities in SARSCoV-2 RdRp assays, we next evaluated cytotoxicity and antiviral activity of HeE1-2Tyr (16), 17, and 18 in cell-based systems. The compounds were initially tested at one single concentration of $50 \mu \mathrm{M}$ against SARS-CoV-2 and FIPV in Vero and CRFK cells, respectively. This initial screening revealed that all compounds at $50 \mu \mathrm{M}$ were not cytotoxic for both cell lines (Figure 2A). Moreover, compounds HeE1-2Tyr (16) and 17 were found to completely inhibit the replication of both coronaviruses (Figure 2B). Surprisingly, compound $\mathbf{1 8}$ was found to be inactive against SARS-CoV-2 and FIPV in both cell-based systems tested $\left(\mathrm{EC}_{50}>50 \mu \mathrm{M}\right)$ (Figure 2B). The inactivity could be explained by its poor cellular uptake or extensive degradation by cellular catabolic enzymes. Therefore, compound $\mathbf{1 8}$ was excluded from further testing.

The cytotoxicity of compounds HeE1-2Tyr (16) and $\mathbf{1 7}$ was studied in detail using Vero, $\mathrm{CaCo}-2$, and CRFK cells in a concentration range from 0 to $50 \mu \mathrm{M}$. Both compounds showed good cytotoxicity profiles for the studied cell lines and were characterized by $\mathrm{CC}_{50}$ values $>50 \mu \mathrm{M}$ (Figure 2C-E; Tables 1-3). Interestingly, compound 17 caused a moderate increase in cell viability in Vero and CaCo-2 cells (to approx. $125 \%$ of untreated cells) but was slightly cytotoxic for CRFK cells (cell viability of approx. 60\%) at the highest concentration tested $(50 \mu \mathrm{M})$ (Figure $2 \mathrm{C}-\mathrm{E}$ ). The observed changes in the viability of cells treated by compound 17 , however, did not affect the $\mathrm{CC}_{50}$ values, which were calculated to be $>50 \mu \mathrm{M}$ for all the cell lines tested. 

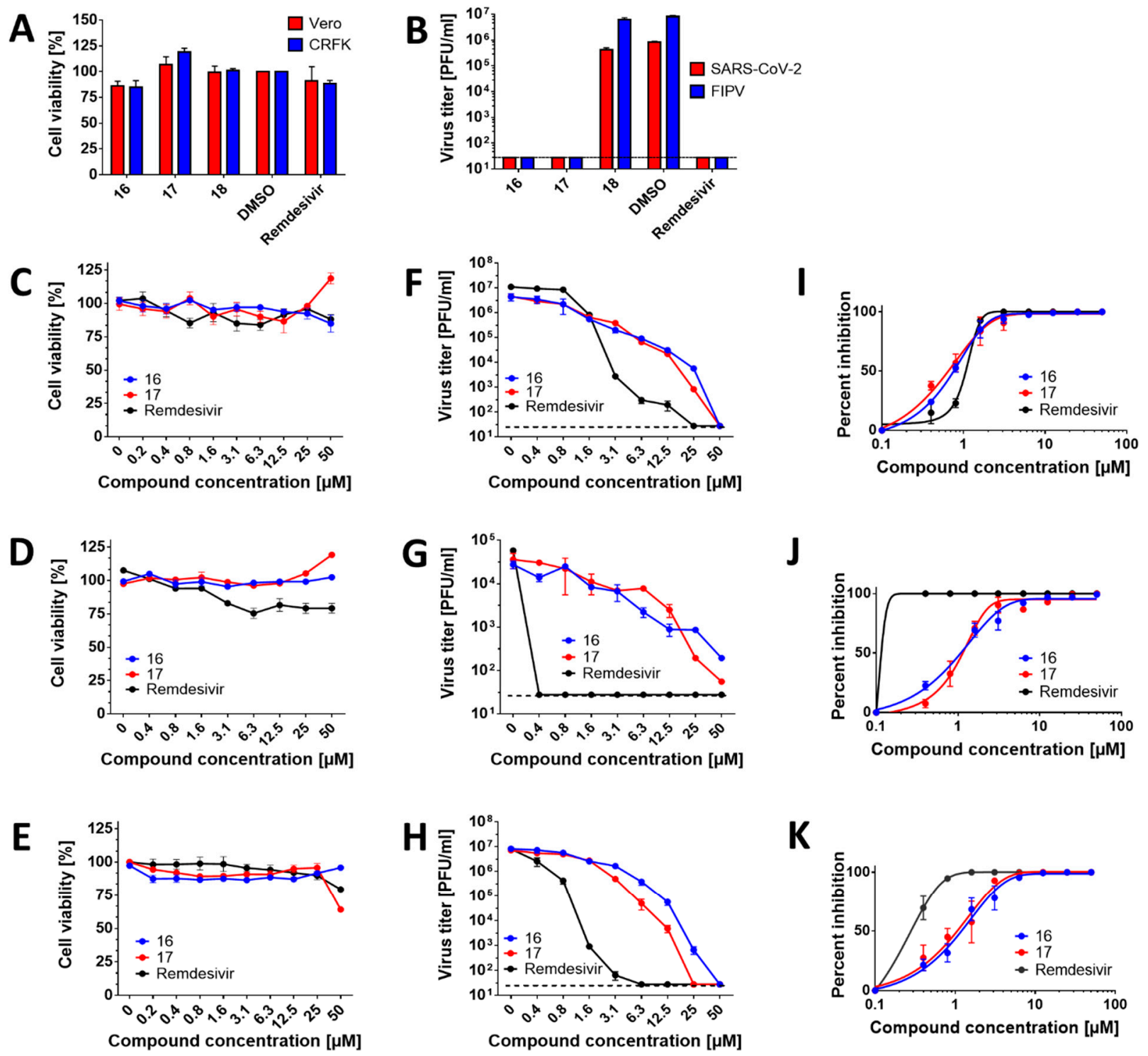

Figure 2. Antiviral efficacy and cytotoxicity of the studied RdRp inhibitors in cell-based assays. (A) Cytotoxicity of the indicated compounds in Vero and CRFK cells. The cell monolayers were treated with the compounds $(50 \mu \mathrm{M})$ and incubated for $48 \mathrm{~h}$. The cell-mediated conversion of tetrazolium salt WST-8 to formazan was monitored by absorbance measurement $(450 \mathrm{~nm})$. Cytotoxicity was expressed in terms of cell viability percentage. (B) Anti-SARS-CoV-2 and anti-FIPV efficacies of the indicated compounds in Vero and CRFK cells, respectively. The cell monolayers were treated with the compounds $(50 \mu \mathrm{M})$, infected with the respective virus at a MOI of 0.1 , and incubated for $48 \mathrm{~h}$. The supernatant media were collected, and viral titers were determined by plaque assays. (C-E) Dose-dependent cytotoxic effects of the compounds in Vero (C), CaCo-2 (D), and CRFK (E) cells. The cell monolayers were treated with the compounds in the concentration range from 0 to $50 \mu \mathrm{M}$ and incubated for $48 \mathrm{~h}$. Cytotoxicity was determined, as described for (A). (F,G) Dose-dependent anti-SARS-CoV-2 activity of the compounds in Vero $(\mathbf{F})$ and $\mathrm{CaCo}-2(\mathrm{G})$ cells. The cell monolayers were treated with the compounds in the concentration range $0-50 \mu \mathrm{M}$ and simultaneously infected with SARS-CoV-2 at a MOI of 0.1. The infected cells were incubated with the compounds for 48 h p.i., and viral titers were determined using the plaque assay. (H) Dose-dependent anti-FIPV activity of the compounds in CRFK cells. The protocol was the same as described for (F,G). (I-K) Inhibitory curves for the indicated compounds in Vero (I), CaCo-2 (J), and CRFK (K) cells. The mean titers from three biological replicates are shown, and error bars indicate standard errors of the mean $(n=3)$. The horizontal dashed line indicates the minimum detectable threshold of $1.44 \log _{10} \mathrm{PFU} / \mathrm{mL}$. 
Table 1. Anti-SARS-CoV-2 activity and cytotoxicity of the tested compounds in Vero cells.

\begin{tabular}{cccc}
\hline Compound & $\mathrm{EC}_{\mathbf{5 0}}(\boldsymbol{\mu M})(\mathbf{9 5} \% \mathbf{C I})^{\mathbf{a}, \mathbf{b}}$ & $\mathrm{CC}_{\mathbf{5 0}}(\boldsymbol{\mu M})^{\mathbf{a}}$ & $\mathbf{S I}^{\mathbf{c}}$ \\
\hline $\mathbf{1 6}$ & $0.6535(0.4376-0.9760)$ & $>50$ & $>76.5$ \\
$\mathbf{1 7}$ & $0.5273(0.4423-0.6286)$ & $>50$ & $>94.8$ \\
$\mathbf{1 8}$ & $>50$ & $>50$ & $>1$ \\
Remdesivir & $0.9012(0.7997-1.016)$ & $>50$ & $>55.5$ \\
\hline
\end{tabular}

[a] Determined from three independent experiments. [ $\left.{ }^{\mathrm{b}}\right]$ Expressed as a $50 \%$ reduction in viral titers and calculated as inflection points of sigmoidal inhibitory curves which were obtained by a nonlinear fit of transformed inhibitor concentrations versus normalized response using GraphPad Prism 7.04 (GraphPad Software, Inc., USA). $\left[{ }^{\mathrm{C}}\right] \mathrm{CC}_{50} / \mathrm{EC}_{50}$.

Table 2. Anti-SARS-CoV-2 activity and cytotoxicity of the tested compounds in CaCo-2 cells.

\begin{tabular}{cccc}
\hline Compound & $\mathrm{EC}_{\mathbf{5 0}}(\boldsymbol{\mu M})(\mathbf{9 5} \% \mathbf{C I})^{\mathbf{a}, \mathbf{b}}$ & $\mathbf{C C}_{\mathbf{5 0}}(\boldsymbol{\mu M})^{\mathbf{a}}$ & SI $^{\mathbf{c}}$ \\
\hline $\mathbf{1 6}$ & $0.9493(0.5131-1.756)$ & $>50$ & $>52.7$ \\
$\mathbf{1 7}$ & $0.9959(0.5427-1.827)$ & $>50$ & $>50.2$ \\
$\mathbf{1 8}$ & $>25$ & $>50$ & $>2$ \\
Remdesivir & $<0.3$ & $>50$ & $>216.9$ \\
\hline
\end{tabular}

For $\left[{ }^{\mathrm{a}-\mathrm{c}}\right]$ see Table 1.

Table 3. Anti-FIPV activity and cytotoxicity of the tested compounds in CRFK cells.

\begin{tabular}{cccc}
\hline Compound & $\mathrm{EC}_{\mathbf{5 0}}(\boldsymbol{\mu M})(\mathbf{9 5} \% \mathbf{C I})^{\mathbf{a}, \mathbf{b}}$ & $\mathrm{CC}_{\mathbf{5 0}}(\boldsymbol{\mu M})^{\mathbf{a}}$ & $\mathbf{S I}^{\mathbf{c}}$ \\
\hline $\mathbf{1 6}$ & $1.062(0.8188-1.377)$ & $>50$ & $>47.1$ \\
$\mathbf{1 7}$ & $0.9989(0.8274-1.206)$ & $>50$ & $>50.1$ \\
$\mathbf{1 8}$ & $>50$ & $>50$ & $>1$ \\
Remdesivir & $0.2230(0.1694-0.2937)$ & $>50$ & $>224.2$ \\
\hline For $\left.{ }^{\mathrm{a}-\mathrm{c}}\right]$ see
\end{tabular}

For $\left[{ }^{\mathrm{a}-\mathrm{c}}\right]$ see Table 1.

We further evaluated the dose-dependent, anti-coronaviral activities of compounds HeE1-2Tyr (16) and 17. Anti-SARS-CoV-2 potency of both compounds in Vero cells reached sub-micro molar concentrations, with $\mathrm{EC}_{50}$ values of $653.5 \mathrm{nM}$ (for 16) and $527.3 \mathrm{nM}$ (for 17). These values were similar or even better than those of remdesivir $\left(\mathrm{EC}_{50}=901.2 \mathrm{nM}\right)$ (Figure 2F,I, Table 1). Although the $\mathrm{EC}_{50}$ values for HeE1-2Tyr (16) and $\mathbf{1 7}$ were slightly lower compared with those for remdesivir, the growth inhibition curve slopes for remdesivir were substantially steeper than those for HeE1-2Tyr (16) and 17, indicating that remdesivir had a superior inhibitory profile over HeE1-2Tyr (16) and 17. In CaCo-2 cells, compounds HeE1-2Tyr (16) and 17 showed EC $_{50}$ values close to $1 \mu \mathrm{M}(949.3$ and $995.9 \mathrm{nM}$, respectively) and had somewhat lower antiviral potencies compared with remdesivir $\left(\mathrm{EC}_{50}<300 \mathrm{nM}\right)$ (Figure 2G,J, Table 2). Because of their low cytotoxicity, both compounds were characterized by relatively high selectivity indexes ( $>70$ in Vero cells and $>50$ in CaCo2 cells) (Tables 1 and 2). In vitro replication of FIPV, another member of the Coronaviridae family used in our antiviral study, was also strongly suppressed with compounds HeE1$2 \mathrm{Tyr}(\mathbf{1 6})$ and 17. The anti-FIPV activity of these compounds was characterized by $\mathrm{EC}_{50}$ values of about $1 \mu \mathrm{M}$, was approx. 5 -fold lower compared with remdesivir $\left(\mathrm{EC}_{50}=223 \mathrm{nM}\right)$, and showed selectivity indexes exceeding 40 (Figure 2H,K, Table 3).

In conclusion, HeE1-2Tyr (16) and its derivatives are potent non-nucleoside inhibitors of coronaviral RdRp that probably act as competitive inhibitors interacting via RNA template tunnel in contrast to chain terminator inhibitors such as remdesivir. These compounds represent suitable candidates for the preparation of clinically usable compounds against SAR-CoV-2 and other coronaviruses, as we have shown with an FIPV example. Compounds HeE1-2Tyr (16) and $\mathbf{1 7}$ showed significant activity against these coronaviruses in cell cultures. We have also unveiled that one of the mechanisms of action of these compounds is the inhibition of RdRp SARS-CoV-2. This key virus enzyme was inhibited by these compounds, with HeE1-2Tyr (16) and 17 showing significantly higher activity compared to 18. This suggests that the phenyl substituent on the pyridinone portion of the 
backbone may significantly affect the activity of these derivatives, both in the polymerase assay and in the cell lines. Clearly, further chemical modification and optimization to enhance potency and physicochemical properties will be required for the eventual use of this type of compounds in clinical practice; however, the derivatives of HeE1-2Tyr (16) may be one of the rare non-nucleoside inhibitors of coronavirus replication that interfere with RdRp, a key enzyme of these viruses. Although remdesivir is the only RdRp-targeting inhibitor approved by the FDA and EMA for clinical use, some studies suggest that its in vivo effects are suboptimal. Experience with other viral diseases suggests that combinations with other polymerase inhibitors can provide a significant synergistic effect and prevent the evolution of drug-resistant virus mutants; therefore, the introduction of new types of inhibitors may have a significant impact on improving the clinical outcome for patients.

Supplementary Materials: The following are available online at https:/ / www.mdpi.com/article/10.339 0/v13081585/s1, Supplementary File S1: chemical synthesis of the compounds and NMR spectra.

Author Contributions: M.D. and E.K. contributed equally; conceptualization, M.D., D.R., E.B. and R.N.; synthesis M.D. and M.Š.; methodology, E.K., L.E., P.S. (Petra Straková), P.S. (Pavel Svoboda), K.K.; writing_original draft preparation, M.D., E.K., L.E., D.R., E.B. and R.N.; supervision and funding acquisition, L.E., D.R., E.B. and R.N. All authors have read and agreed to the published version of the manuscript.

Funding: The work was supported by the European Regional Development Fund; OP RDE; Project: “Chemical Biology for Drugging Undruggable Targets (ChemBioDrug)" (No. CZ.02.1.01/0.0/0.0/16_019/ 0000729), Ministry of Health of the Czech Republic (grant NU20-05-00472), the Czech Academy of Sciences (RVO: 61388963), and Gilead Sciences Inc. This study was also supported by a grant from the Ministry of Education, Youth, and Sports of the Czech Republic (grant LTAUSA18016) (to L.E. and R.N.).

Institutional Review Board Statement: Not applicable.

Informed Consent Statement: Not applicable.

Data Availability Statement: Not applicable.

Conflicts of Interest: The research was partially sponsored by Gilead Sciences Inc., Foster City, CA, USA.

\section{References}

1. Cui, J.; Li, F.; Shi, Z.L. Origin and evolution of pathogenic coronaviruses. Nat. Rev. Microbiol. 2019, 17, 181-192. [CrossRef]

2. De Wit, J.J.; Cook, J.K.A. Spotlight on avian coronaviruses. Avian Pathol. 2020, 49, 313-316. [CrossRef]

3. Monchatre-Leroy, E.; Boue, F.; Boucher, J.M.; Renault, C.; Moutou, F.; Gouilh, M.A.; Umhang, G. Identification of Alpha and Beta Coronavirus in Wildlife Species in France: Bats, Rodents, Rabbits, and Hedgehogs. Viruses 2017, 9, 364. [CrossRef]

4. Chen, Y.; Liu, Q.Y.; Guo, D.Y. Emerging coronaviruses: Genome structure, replication, and pathogenesis. J. Med. Virol. 2020, 92, 418-423. [CrossRef]

5. De Wit, E.; Van Doremalen, N.; Falzarano, D.; Munster, V.J. SARS and MERS: Recent insights into emerging coronaviruses. Nat. Rev. Microbiol. 2016, 14, 523-534. [CrossRef]

6. Zumla, A.; Chan, J.F.W.; Azhar, E.I.; Hui, D.S.C.; Yuen, K.-Y. Coronaviruses-Drug discovery and therapeutic options. Nat. Rev. Drug Discov. 2016, 15, 327-347. [CrossRef]

7. Gorbalenya, A.E.; Baker, S.C.; Baric, R.S.; De Groot, R.J.; Drosten, C.; Gulyaeva, A.A.; Haagmans, B.L.; Lauber, C.; Leontovich, A.M.; Neuman, B.W.; et al. The species Severe acute respiratory syndrome-related coronavirus: Classifying 2019-nCoV and naming it SARS-CoV-2. Nat. Microbiol. 2020, 5, 536-544. [CrossRef]

8. Lu, L.; Zhong, W.Y.; Bian, Z.W.; Li, Z.M.; Zhang, K.; Liang, B.X.; Zhong, Y.Z.; Hu, M.J.; Lin, L.; Liu, J.; et al. A comparison of mortality-related risk factors of COVID-19, SARS, and MERS: A systematic review and meta-analysis. J. Infect. 2020, 81, E18-E25. [CrossRef]

9. Finelli, L.; Gupta, V.; Petigara, T.; Yu, K.; Bauer, K.A.; Puzniak, L.A. Mortality Among US Patients Hospitalized With SARS-CoV-2 Infection in 2020. JAMA Netw. Open 2021, 4, e216556. [CrossRef]

10. Tumban, E. Lead SARS-CoV-2 Candidate Vaccines: Expectations from Phase III Trials and Recommendations Post-Vaccine Approval. Viruses 2021, 13, 54. [CrossRef]

11. Wu, D.; Koganti, R.; Lambe, U.P.; Yadavalli, T.; Nandi, S.S.; Shukla, D. Vaccines and Therapies in Development for SARS-CoV-2 Infections. J. Clin. Med. 2020, 9, 1885. [CrossRef] 
12. Pedersen, O.S.; Pedersen, E.B. Non-nucleoside reverse transcriptase inhibitors: The NNRTI boom. Antivir. Chem. Chemother. 1999, 10, 285-314. [CrossRef]

13. Dayal, V.; Kumar, A.; Jha, S.K.; Sharan, A.; Kumar, U.; Shahi, S.K. Viral Hepatitis ( plus Antiviral Therapy) Combination therapy of lamivudine and adefovir in patients of HBeAg positive chronic hepatitis B. J. Gastroenterol. Hepatol. $2013,28,419$.

14. Das, D.; Pandya, M. Recent Advancement of Direct-acting Antiviral Agents (DAAs) in Hepatitis C Therapy. Mini-Rev. Med. Chem. 2018, 18, 584-596. [CrossRef]

15. Vicenti, I.; Zazzi, M.; Saladini, F. SARS-CoV-2 RNA-dependent RNA polymerase as a therapeutic target for COVID-19. Expert Opin. Ther. Pat. 2021, 31, 325-337. [CrossRef]

16. Perry, J.K.; Appleby, T.C.; Bilello, J.P.; Feng, J.Y.; Schmitz, U.; Campbell, E.A. An atomistic model of the coronavirus replicationtranscription complex as a hexamer assembled around nsp15. bioRxiv 2021. [CrossRef]

17. Hillen, H.S.; Kokic, G.; Farnung, L.; Dienemann, C.; Tegunov, D.; Cramer, P. Structure of replicating SARS-CoV-2 polymerase. Nature 2020, 584, 154-156. [CrossRef]

18. Pruijssers, A.J.; George, A.S.; Schafer, A.; Leist, S.R.; Gralinksi, L.E.; Dinnon, K.H.; Yount, B.L.; Agostini, M.L.; Stevens, L.J.; Chappell, J.D.; et al. Remdesivir Inhibits SARS-CoV-2 in Human Lung Cells and Chimeric SARS-CoV Expressing the SARS-CoV-2 RNA Polymerase in Mice. Cell Rep. 2020, 32, 107940. [CrossRef]

19. Yin, W.C.; Luan, X.D.; Li, Z.H.; Zhou, Z.W.; Wang, Q.X.; Gao, M.Q.; Wang, X.X.; Zhou, F.L.; Shi, J.J.; You, E.R.; et al. Structural basis for inhibition of the SARS-CoV-2 RNA polymerase by suramin. Nat. Struct. Mol. Biol. 2021, 28, 319-325. [CrossRef]

20. Li, Q.; Yi, D.; Lei, X.; Zhao, J.; Zhang, Y.; Cui, X.; Xiao, X.; Jiao, T.; Dong, X.; Zhao, X.; et al. Corilagin inhibits SARS-CoV-2 replication by targeting viral RNA-dependent RNA polymerase. Acta Pharm. Sin. B 2021, 11, 1555-1567. [CrossRef]

21. Jin, Y.H.; Min, J.S.; Jeon, S.; Lee, J.; Kim, S.; Park, T.; Park, D.; Jang, M.S.; Park, C.M.; Song, J.H.; et al. Lycorine, a non-nucleoside RNA dependent RNA polymerase inhibitor, as potential treatment for emerging coronavirus infections. Phytomedicine 2021, 86, 153440. [CrossRef]

22. Agrawal, N.; Goyal, A. Potential Candidates against COVID-19 Targeting RNA-Dependent RNA Polymerase: A Comprehensive Review. Curr. Pharm. Biotechnol. 2021. [CrossRef]

23. Tarantino, D.; Cannalire, R.; Mastrangelo, E.; Croci, R.; Querat, G.; Barreca, M.L.; Bolognesi, M.; Manfroni, G.; Cecchetti, V.; Milani, M. Targeting flavivirus RNA dependent RNA polymerase through a pyridobenzothiazole inhibitor. Antivir. Res. 2016, 134, 226-235. [CrossRef]

24. Cannalire, R.; Tarantino, D.; Piorkowski, G.; Carletti, T.; Massari, S.; Felicetti, T.; Barreca, M.L.; Sabatini, S.; Tabarrini, O.; Marcello, A.; et al. Broad spectrum anti-flavivirus pyridobenzothiazolones leading to less infective virions. Antivir. Res. 2019, $167,6-12$. [CrossRef]

25. Cannalire, R.; Chan, K.W.K.; Burali, M.S.; Gwee, C.P.; Wang, S.; Astolfi, A.; Massari, S.; Sabatini, S.; Tabarrini, O.; Mastrangelo, E.; et al. Pyridobenzothiazolones Exert Potent Anti-Dengue Activity by Hampering Multiple Functions of NS5 Polymerase. ACS Med. Chem. Lett. 2020, 11, 773-782. [CrossRef] [PubMed]

26. Felicetti, T.; Burali, M.S.; Gwee, C.P.; Chan, K.W.K.; Alonso, S.; Massari, S.; Sabatini, S.; Tabarrini, O.; Barreca, M.L.; Cecchetti, V.; et al. Sustainable, three-component, one-pot procedure to obtain active anti-flavivirus agents. Eur. J. Med. Chem. 2021, 210, 112992. [CrossRef]

27. Konkolova, E.; Dejmek, M.; Hrebabecky, H.; Sala, M.; Boserle, J.; Nencka, R.; Boura, E. Remdesivir triphosphate can efficiently inhibit the RNA-dependent RNA polymerase from various flaviviruses. Antivir. Res. 2020, 182, 104899. [CrossRef] [PubMed]

28. De Madrid, A.T.; Porterfield, J.S. A simple micro-culture method for the study of group B arboviruses. Bull. World Health Organ. 1969, 40, 113-121. [PubMed]

29. Eyer, L.; Valdes, J.J.; Gil, V.A.; Nencka, R.; Hrebabecky, H.; Sala, M.; Salat, J.; Cerny, J.; Palus, M.; De Clercq, E.; et al. Nucleoside Inhibitors of Tick-Borne Encephalitis Virus. Antimicrob. Agents Chemother. 2015, 59, 5483-5493. [CrossRef] 